\title{
SCIENTIFIC
}

MUKACHEVO

STATE

UNVERSITY ECONOMICS

Volume 8, No. 2, 101-107

Journal homepage: https://economics-msu.com.ua/en

\section{Level of Ecological and Economic Diversification: A Methodology for Assessing the Sustainability of Agricultural Enterprises}

\author{
Svitlana I. Strapchuk* \\ Kharkiv National Agrarian University named after V.V. Dokuchaev \\ 62483, KhNAU study town, p/v "Dokuchaevske-2", Kharkiv Region, Ukraine
}

\begin{abstract}
As a global initiative within the framework of the United Nations Environment Programme framework, the Economics of Ecosystems and Biodiversity emphasises the importance of applying a systematic approach to the assessment of Natural Resources and the need to introduce new forms of economic growth to the sustainable development of enterprises. Existing management practices of agricultural enterprises, such as monoculture, create a constant monotonous load on the soil and lead to a decrease in humus content, contribute to erosion, but remain highly profitable. Changing the forms of economic growth in favour of introducing sustainable practices such as organic production, sustainable intensification, and eco-production requires appropriate sources of financing, a high level of environmental awareness, and comprehensive methods for assessing environmental and economic factors. The purpose of the study is to substantiate a methodological approach to a comprehensive assessment of the ecological and economic diversification of an enterprise based on the principles of sustainable development, which allows taking into account the level of diversity of cultivated crops in relation to the structure of marketable products. To achieve this goal, statistical information on the activities of agricultural enterprises in the Kharkivska Oblast was used, as well as monographic, graphical and statistical methods of research. Data analysis and processing were performed using specialised software: Microsoft Excel and Statistica 10. The study presents the developed and tested coefficient of ecological and economic diversification, which allows assessing the level of agrobiodiversity of sown areas and marketable products of agricultural enterprises based on the management results for 2019. The coefficient is based on information theory in the context of applying the Shannon-Weaver index. As a result of the search for the relationship between the coefficient of ecological and economic diversification and profit per 1 hectare, the statement about the gradual loss of profitability during the growth of the number of types of crops is confirmed. However, there are enterprises that maintain profitability during the expansion of the acreage structure. The practical significance of the findings obtained is allows assessing the possibility of adapting the structure of acreage to market conditions, taking into account environmental and economic factors
\end{abstract}

Keywords: sustainable development, biodiversity, monoculture, agricultural enterprise, coefficient of ecological and economic diversification, economic efficiency

Received: 13.01.2021, Revised: 19.04.2021, Accepted: 15.06.2021

Suggested Citation: Strapchuk, S.I. (2021). Level of ecological and economic diversification: A methodology for assessing the sustainability of agricultural enterprises. Scientific Bulletin of Mukachevo State University. Series “Economics”, 8(2), $101-107$. 


\section{Introduction}

As the world's population grows, so does the need for more sustainable food and agricultural systems designed to meet human needs while minimising environmental damage and reducing further loss of biodiversity. The Economics of Ecosystems and Biodiversity (TEEB) as a global initiative within the United Nations Environment Programme focuses on how to support the transition to sustainable agricultural systems, which, in addition to economic, should provide social and environmental impact [1].

The available natural resources and favourable climatic conditions that have ensured the growth of arable land in Ukraine (43.4 million hectares or $2.3 \%$ of the world's area) [2] are an incentive to increase the export potential of profitable agricultural products. Further intensification and expansion of agricultural land, subject to the application of traditional management practices, can have a detrimental impact on the environment and biodiversity, if the consequences of such an impact are not prevented at the level of effective solutions. One of the directions of implementing aspects of the Sustainable Development Policy in agriculture is to increase the level of diversification of acreage that forms biodiversity-friendly landscapes. In this aspect, the issue of finding a compromise between preserving the environment and using the economic potential of the industry is relevant, the solution of which lies in the plane of innovative circular business models, promising management practices in agriculture, biomimicry, etc. However, barriers to sustainable development are the traditional views of most producers on farming practices and the lack of financial resources to invest in sustainability.

The introduction of ideas for sustainable agricultural development is possible during the gradual transition from traditional practices to more sustainable ones, such as organic production, sustainable intensification, etc. This requires diversification of production, which allows obtaining products with different consumer characteristics, which determines its different purpose. In the process of finding an answer to the question of assessing the level of diversification, which can take into account environmental and economic factors in a complex, the author of this study developed a coefficient that allows combining the structures of acreage and marketable products. A comprehensive assessment of the state of an agricultural enterprise takes into account the diversity and complexity of combining factors based on the coefficient of ecological and economic diversification. Unlike existing approaches, such an assessment takes into account the principles of sustainable development, provides for a combination of environmental and economic components, and allows taking into account the dependence of the enterprise on the agrobiodiversity of the cultivated area and market fluctuations in demand affecting the structure of market products.

In the agricultural sector, the idea of more sustainable agriculture has gained popularity since the publication of the report by G.H. Brundtland [3] and due to the emergence of the triple bottom line (TBL) [4]. However, the characteristics of sustainable development in agriculture reflect a wide variety of aspects [3]. Many studies have attempted to link sustainable agricultural development to various agriculturalpractices(orsystems), suchasorganicproduction [5]; conservation agriculture [6]; biological production [7]; ecological production, eco-production [8]; sustainable intensification [9], etc.

The expansion of monoculture and the excessive use of herbicides has led to a sharp decline in plant diversity in agricultural landscapes, with negative consequences for the versatility of ecosystems and sustainable production $[10 ; 11]$. In order to reduce the negative impact and increase the heterogeneity of landscapes, some authors propose a number of measures that include crop diversification, plant conservation and agricultural environment schemes [12; 13]. Effective assessment of plant diversity in agricultural landscapes and determination of the level of crop diversification are fundamental to the successful implementation of measures.

In addition, to develop a systematic vision of the problems of sustainable development in agriculture, the studies of the authors were examined $[14 ; 15]$, the results of which indirectly influenced the establishment of ideas about certain aspects of sustainability inherent in the industry. In particular, the study [14] indicates the dialectical nature of sustainable development, which can be implemented in an innovation-oriented cluster model of regional development, the revival of traditional production and consumption of local food, the advantages of the latter are technological uniqueness, high quality and savings on logistics costs. In [15], sustainable development is considered as a balanced dynamic equilibrium that has specific features of reproduction in agriculture. The author suggests an innovative scenario of development in the short term, in which innovative solutions that ensure the growth of production volumes against the background of efficient use of natural resources are an additional source of sustainability.

The purpose of the study is a substantiation of a methodological approach to a comprehensive assessment of the ecological and economic diversification of an enterprise based on the principles of sustainable development, which allows taking into account the level of diversity of cultivated crops in relation to the structure of marketable products. For the furtherance of this goal, a task was set and solved on the development of a comprehensive assessment of the level of enterprise diversification, taking into account environmental and economic components, as an attempt to expand the understanding of assessing aspects of sustainable agricultural development.

\section{Materials and Methods}

To achieve the above goal, the study used statistical information on the activities of 529 agricultural producers of the Kharkivska Oblast in 2019, which make up the general population for the region and can act as a sample 
population for Ukraine. The information was processed based on the statistical reports of existing business entities of the Kharkivska Oblast [16]. The anonymity of data was ensured by presenting information in a grouped and systematised form.

The stages of the study provide for determining the structure of acreage and marketable products for each agricultural enterprise in the sample, calculating the proposed coefficient that reflects the combined effect of environmental and economic factors, and further correlating its values with the indicator of economic efficiency of management. The establishment of the coefficient assessment scale allowed identifying the reasons for assigning certain enterprises to the selected intervals when taking into account the level of profit per 1 ha of land area. The theoretical and methodological basis of the study is a set of methods, approaches to scientific knowledge, scientific developments on the economic development of agricultural enterprises based on the principles of sustainability.

To implement the purpose and objectives of the study, the following methods were used: monographic approach - when studying the reports of international organisations on sustainable agricultural development; statistical and economic approach - to collect and process statistical data on the existing structure of acreage and the structure of marketable products of agricultural enterprises in the region, as well as to determine the relationships and interdependencies of the coefficient and performance indicators; graphical approach - used for visual display of the obtained results; comparative approach - used to compare the causal relationships of economic phenomena identified in the course of the study when analysing trends in the development of crop production.

As a result of using the coefficient of ecological and economic diversification, the sample was optimised and reduced to 495 business entities due to the exclusion of enterprises from the general population that were engaged either only in cultivation and did not sell products, or only in their sale. To analyse the influence of the coefficient of environmental and economic diversification on performance indicators, methods of computer processing and analysis of information using an Excel spreadsheet processor were used, followed by data processing in the Statistica software package. The initial information during the study was statistical data of the State Statistics Service of Ukraine, international organisations, annual financial statements of agricultural enterprises, papers by Ukrainian and foreign scientists and practitioners, the findings of their own studies on the use of sustainable development practices by agricultural enterprises.

\section{Results and Discussion}

Assessment of the level of acreage diversification, adjusted for the indicator of the structure of marketable products, allows determining for each business entity how much the farm applies certain aspects of sustainability in its activities. Environmental indicators of sustainable development measure biodiversity using a number of indicators, which include: population of a country, region or local area; species richness (number of rare species); habitat area; greenhouse gas emissions $\left(\mathrm{CO}^{2}\right.$ eq.); quantitative $\left(\mathrm{m}^{3}\right)$ and qualitative (mg of pollutant per $\mathrm{ml}$ ) parameters of water resources and their availability; type or change of land cover (\% of conversion) [17].

Considering agriculture as a type of economic activity, the author proposes a coefficient for evaluating the artificially created species structure of sown areas, which forms an enterprise based on ecological and economic factors. This refers to the coefficient of ecological and economic diversification (CEED) (1).

$$
\mathrm{CEED}=-\sum_{i=1}^{n} p_{i s} L N p_{i s} \cdot \sqrt{\sum_{i=1}^{n} p_{i q p} \cdot L N p_{i q p}}
$$

where $p_{i s}$ - specific weight of crops in the structure of areas, coef.; $p_{\text {iqp }}$ - specific weight of the corresponding marketable products in their total volume, coef.; $L N$ - natural logarithm with the basis of an irrational constant.

This indicator is based on the Shannon-Weaver index, which uses information theory to assess the species constancy and community diversity. It is calculated as the sum of the products of the fractions of individual populations in the total sample and their natural logarithms [18]. The amount of meaningful information can reduce uncertainty. The index is often used in environmental research because it is not significantly affected by the sample size, and its application allows covering significant amounts of information using a single mathematical expression. In addition, the author suggests taking into account the structure of acreage and marketable products of the enterprise in the coefficient of ecological and economic diversification, which allows assessing the possibility of adapting the structure of areas to market conditions with optimal use of natural resources.

Having calculated the coefficient of ecological and economic diversification for each enterprise in the aggregate, its rating scale was determined with gradation to low (from 0 to 1 ), medium (from 1 to 1.5 ) and high (more than 1.5). The economic content of the indicator is that with its growth, the possibility of ensuring sustainable production at the enterprise level increases, which, in turn, may be associated with a decrease in profitability compared to traditional agriculture and the monoculture characteristic of it in recent years (Fig. 1). 


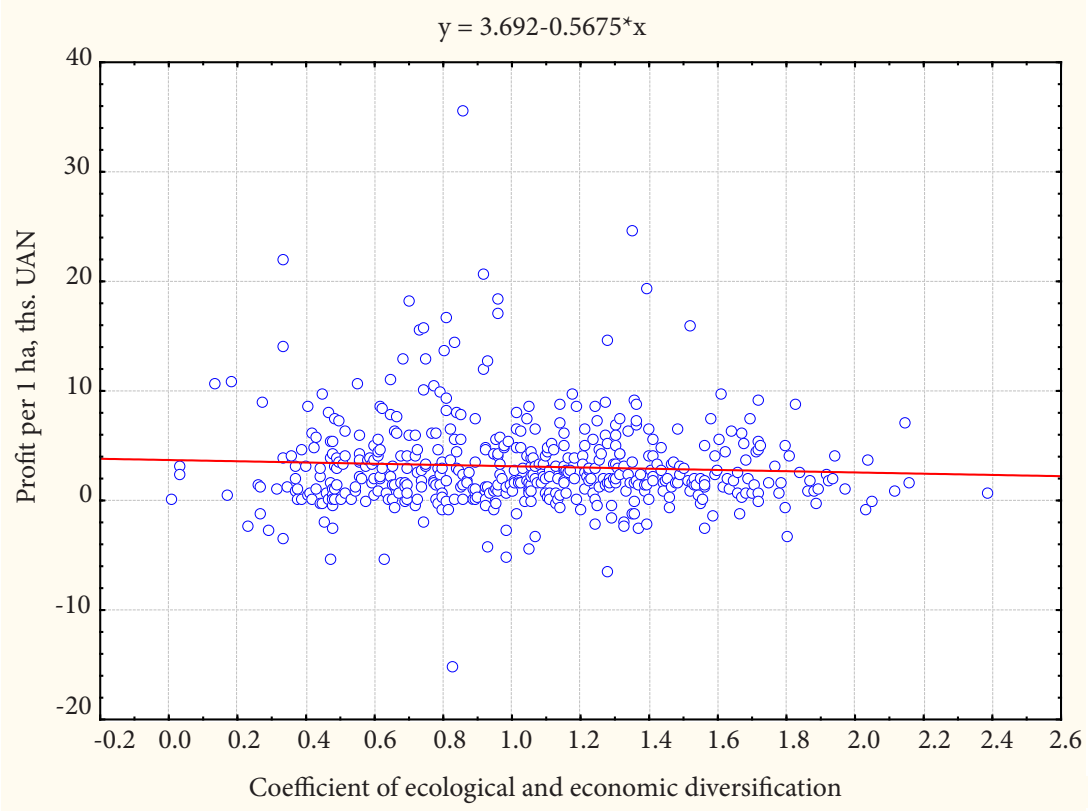

Figure 1. The graph of the function of dependence of profit per 1 ha on the coefficient of ecological and economic diversification of agricultural enterprises in the Kharkivska Oblast

Source: compiled by the author based on the data of financial reports of business entities of the industry [16]

This relationship was revealed as a result of regression analysis and an equation of dependence of profit per 1 ha on the coefficient of ecological and economic diversification of agricultural enterprises was obtained, which characterises the downward dynamics of profit per 1 ha with an increase in this coefficient.

Agricultural enterprises of the Kharkivska Oblast in 2019 specialised in growing various crops, but the vast majority used the practice of monoculture, in particular, $3 \%$ of them grew exclusively wheat, $1.5 \%$ - only sunflower, and more than $35 \%$ of enterprises in the structure of sown areas had only two crops - sunflower and wheat [16]. Monoculture creates a constant monotonous load on the soil and leads to a decrease in the humus content, contributes to erosion, and so on. Among the factors identified as the main threats to the further provision of soil ecosystem services, the loss of soil biodiversity, as indicated in [19], is the fourth most important after soil erosion, reduction of organic carbohydrates and nutrient imbalance.

The study of data obtained from statistical reports of enterprises allowed grouping the results obtained at intervals of the developed coefficient of ecological and economic diversification and establish the relationship between it and quantitative indicators of the area of management, yield, profit per 1 ha of harvested area, cost of products sold and the cost of mineral fertilisers used for the 2019 harvest (Table 1).

Table 1. Dependence of the coefficient of ecological and economic diversification on individual performance indicators of agricultural enterprises of the Kharkivska Oblast for 2019

\begin{tabular}{|c|c|c|c|c|c|c|c|c|c|c|}
\hline 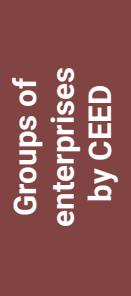 & 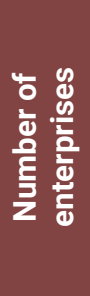 & $\frac{\frac{\pi}{8}}{\frac{\Phi}{4}}$ & 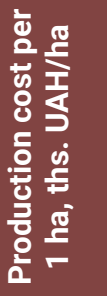 & 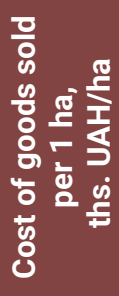 & 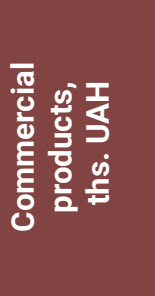 & 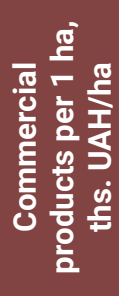 & $\begin{array}{l}\frac{T}{5} \\
S \\
\dot{0} \\
\frac{5}{5} \\
\dot{5} \\
\dot{0} \\
\dot{0}\end{array}$ & 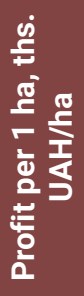 & 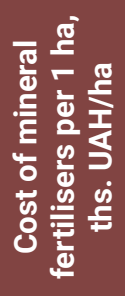 & 䓀 \\
\hline Low & 234 & 1,763 & 23.41 & 22.71 & $32,719.44$ & 26,348 & $5,351.18$ & 3.64 & 3.45 & 0.66 \\
\hline Average & 184 & 2,138 & 14.57 & 13.50 & $35,458.04$ & 16,389 & $6,603.29$ & 2.89 & 3.02 & 1.23 \\
\hline High & 77 & 2448 & 14.41 & 13.69 & $44,075.02$ & 16,190 & 7,977.35 & 2.50 & 2.59 & 1.73 \\
\hline Total & 495 & 2116 & 17.46 & 16.63 & $37,417.5$ & 19,643 & $6,643.94$ & 3.01 & 3.02 & 1.21 \\
\hline
\end{tabular}

Source: compiled by the author based on the data of financial reports of business entities of the industry [16]

Based on the analysis of the relationship between the growth of the level of diversification of agricultural production at the enterprise and the performance indicators of its activities, a number of statements were formed. The latter relate to the available theoretical developments in this context.
If the entire sample of 495 enterprises is divided on the coefficient scale, it will be uneven in terms of the number of enterprises that fall into each of the groups. The largest part of them, namely 234 enterprises, will be in the range from 0 to 1 , which corresponds to a low level of 
ecological and economic diversification and has an average value of this indicator at the level of 0.66 . This group is characterised by the smallest average area at the level of 1763 thousand hectares and a high production cost per 1 ha, which is UAH 23,408 ths. At the same time, the average value of total profit for the year in this group is the lowest, while the profit per 1 ha of area is the highest and amounts to 3.64 ths. UAH/ha. Of particular note is that the cost of mineral fertilisers per 1 ha is also high and amounts to 3.45 ths. UAH/ha.

The second group, identified by the interval of the coefficient of ecological and economic diversification from 1 to 1.5 , which corresponds to its average level, includes 184 enterprises with an average coefficient value of 1.23 and an average area of 2138 hectares. The determining factor is the fact that the production cost per 1 ha is almost twice as low as the indicator of the first group and amounts to 14.57 ths. UAH/ha. The average income per enterprise in this group is UAH 6,603 ths., but per hectare it is UAH 2.89 ths.

The third group, which contains 77 enterprises and is distinguished by the coefficient of ecological and economic diversification from 1.5 and above, is characterised by an average value of the studied coefficient at the level of 1.73 and an average area of 2448 hectares. At the same time, the production cost and the cost of products sold almost do not differ between the medium and high-level groups. The average profit per enterprise is also growing relatively in this group and amounts to UAH 7,977 ths., while per unit area it is the lowest and amounts to UAH 2.5 ths. It is worth noting a gradual decrease in the cost of mineral fertilisers per 1 ha with an increase in the coefficient of ecological and economic diversification.

Of particular interest for further study are examples of management in which the value of the coefficient of ecological and economic diversification is in the range above 1.5 , which is typical for growing a much larger number of crops by an enterprise and is accompanied by a fairly high yield. The formed diagram of the range of dependence of profit per 1 ha at different levels of the coefficient of ecological and economic diversification in agricultural enterprises confirms the data of Figure 1 and details the average levels and maximum range of profit per 1 ha (Fig. 2).

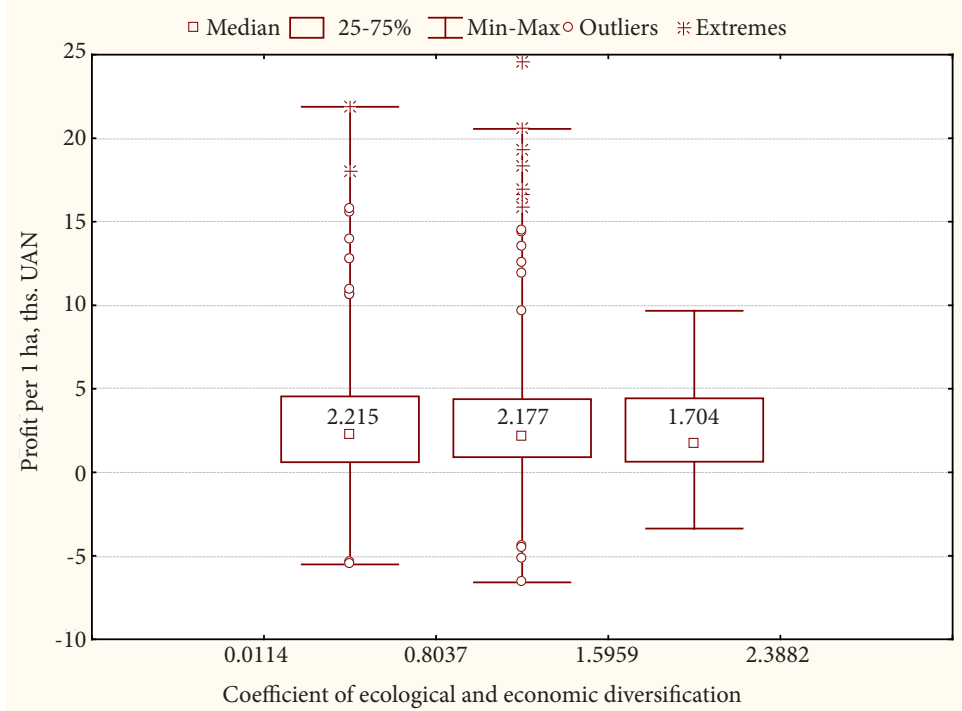

Figure 2. Diagrams of the profit span per 1 ha at different levels of the coefficient of ecological and economic diversification of agricultural enterprises of the Kharkivska Oblast

Source: compiled by the author based on the data of financial reports of business entities of the industry [16]

The scale diagram demonstrates the distribution of enterprises by the level of profit per 1 ha into three groups according to the coefficient of ecological and economic diversification, the median and the range where $50 \%$ of all values fall (from 25 to $75 \%$, respectively). In accordance with this, there is a trend that can be traced by the average values and values of boxes, which indicates a decrease in the level of profit per 1 ha with an increase in the above coefficient.

The results obtained confirm the conclusions of researchers who have studied the issues of sustainable development. The consequences of implementing the principles of sustainability in agricultural production are a change in profitability in different time periods and an increase in the efficiency of using natural resources. An increase in the profitability of enterprises after the introduction of sustainable practices is noted in [20], other researchers claim a decrease in profitability in the short term, since new management principles increase production costs in the short term [21], which correlates with the findings of the study. Further profit growth, provided that agrobiodiversity is observed, can be detected over longer periods of time [21]. But the more obvious consequences are increased soil fertility, reduced soil, air and water pollution, and conservation and savings in the use of natural resources [22].

The search for a link between the economic and environmental components of sustainable development in agriculture requires the selection of mathematical tools for assessing critical levels based on biodiversity. Of particular relevance is the study [18], where the author, having established a significant number of available indicators for assessing diversity and inconsistency with the results of their measurement, claims that the most common indicator 
of diversity is the Shannon-Weaver index. The index evaluates uncertainty as a result of the sampling process and is calculated using logarithms with a base of two - this is the minimum number of "yes/no" questions that are required on average to determine the identity of the selected species. Converting them to an effective number of species is key to a unified and intuitive interpretation of diversity.

In the present study, the coefficient of ecological and economic diversification is proposed for assessing agrobiodiversity, which is based on the mathematical expression of the Shannon-Weaver index and contains components of specific shares of acreage and marketable products to assess the impact of market and natural factors on its change and is radically different from others.

\section{Conclusions}

The increase in agricultural production is conditioned by an increase in demand for food on world markets. The intensification of agricultural producers' activities is often associated, firstly, with environmental problems, which are the due to the lack of knowledge about the relationship between biodiversity, ecosystem functions and ecosystem services, and, secondly, with the uncertainty of environmental trade-offs and thresholds in many areas. The search for directions for implementing sustainable development policies in agriculture has provided an understanding of the need to take into account the mutual influence of environmental and economic factors. Solving economic problems involves ensuring economic growth and adequate assessment tools. One of these solutions is to coordinate the level of diversification of acreage, as a result, the creation of biodiversity-friendly landscapes and structures of marketable products formed under the influence of market factors.
As a result of solving the tasks set, it is proposed to assess an agricultural enterprise's ecological and economic diversification based on the principles of sustainable development, which allows taking into account the level of diversity of crops grown in relation to the structure of marketable products. A comprehensive assessment of the state of an agricultural enterprise, taking into account the diversity and complexity of a combination of factors based on the coefficient of ecological and economic diversification, in contrast to existing approaches, is aimed at implementing the principles of sustainable development and provides for determining the combined impact of environmental and economic components on the efficiency of the enterprise. This allows taking into account the dependence of the company's activities on the agrobiodiversity of the cultivated area and market fluctuations in demand, which affect the structure of marketable products. At the same time, data from the annual financial statements of agricultural business entities were used for the calculation. The results of data processing showed that enterprises with a high value of the coefficient of ecological and economic diversification (from 1.5 and above) had lower profit indicators per 1 ha, but the average profit value per enterprise of this group was relatively higher. In addition, as the coefficient increased, the cost of mineral fertilisers decreased, which may be the result of the introduction of sustainable practices in the activities of agricultural enterprises.

\section{Acknowledgements}

We express our sincere gratitude to Dmytro Viktorovych Shyian, Doctor of Economics, Professor of the Semen Kuznets Kharkiv National Economic University for the ideas that made this study possible.

\section{References}

[1] Pushpam, K. (Ed.). (2012). The economics of ecosystems and biodiversity: Ecological and economic foundations. New York: Routledge.

[2] Teluguntla, P., Thenkabail, P.S, Xiong, J., \& Oliphant, A. (2017). Global food security-support analysis data at $30 \mathrm{~m}$ (GFSAD). Retrieved from https://www.usgs.gov/centers/wgsc/science/global-food-security-support-analysis-data30-m-gfsad?qt-science_center_objects=1\#qt-science_center_objects.

[3] Brundtland, G.H. (1987). Our common future, report of the World Commission on environment and development. In Report of the World Commission on environment and development: Our common future (pp. 5-9). Oxford: Oxford University Press.

[4] Elkington, J. (2004). Enter the triple bottom linel. In A. Henriques, \& J. Richardson (Eds.), The triple bottom line: Does it all add up? (pp. 1-16). London: Earthscan.

[5] Seufert, V., Ramankutty, N., \& Foley, J.A. (2012). Comparing the yields of organic and conventional agriculture. Nature, 485(7397), 229-232.

[6] Kienzler, K.M., Lamers, J.P.A., McDonald, A., Mirzabaev, A., Ibragimov, N., Egamberdiev, O., Ruzibaevd, E., \& Akramkhanov, A. (2012). Conservation agriculture in Central Asia - what do we know and where do we go from here? Field Crops Research, 132, 95-105.

[7] Mzoughi, N. (2011). Farmers' adoption of integrated crop protection and organic farming: Do moral and social concerns matter? Ecological Economics, 70(8), 1536-1545.

[8] McNeely, J.A., \& Scherr, S.J. (2003). Ecoagriculture. Washington: Island Press.

[9] Egan, J.F., Bohnenblust, E., Goslee, S., Mortensen, D., \& Tooker, J. (2014). Herbicide drift can affect plant and arthropod communities. Agricultural Ecosystem Environment, 185, 77-87.

[10] Hooper, D.U., Adair, E.C., Cardinale, B.J., Byrnes, J.E.K., Hungate, B.A., \& Matulich, K.L. (2012). A global synthesis reveals biodiversity loss as a major driver of ecosystem change. Nature, 486(7401), article number 105. 
[11] Bernard, B., \& Lux, A. (2017). How to feed the world sustainably: An overview of the discourse on agroecology and sustainable intensification? Regional Environmental Change, 17(5), 1279-1290.

[12] Batáry, P., Dicks, L.V., Kleijn, D., \& Sutherland, W.J. (2015). The role of agri-environment schemes in conservation and environmental management. Conservation Biology, 29(4), 1006-1016.

[13] Fahrig, L. (2017). Ecological responses to habitat fragmentation per se. Annual Review of Ecology, Evolution, and Systematics, 48(1), 1-23.

[14] Samofatova, V.A. (2018). Sustainable development of agro-food sphere of the region: Theory, methodology, management. Odesa: Astroprint.

[15] Uzhva, A.M. (2017). Sustainable development of agrarian business of agricultural producers in the region: Theory, methodology, practice. Mykolaiv: FOP Shvets V.M.

[16] Official website of the Main Department of Statistics in Kharkiv Region. (n.d.). Retrieved from http://kh.ukrstat.gov.ua/.

[17] Kanter, D.R., Musumba, M., Wood, S.L.R., Palm, C., Antle, J., Balvanera, P., \& Andelman, S. (2018). Evaluating agricultural trade-offs in the age of sustainable development. Agricultural Systems, 163, 73-88.

[18] Jost, L. (2006). Entropy and diversity. Oikos, 113(2), 363-375. doi: 10.1111/j.2006.0030-1299.14714.x.

[19] Orgiazzil, A., Bardgett, R.D., \& Barrios, E. (Eds.). (2015). Global soil biodiversity atlas. Luxembourg: Office of the European Union.

[20] Martin, S., Rieple, A., Chang, J., Boniface, B., \& Ahmed, A. (2015). Small farmers and sustainability: Institutional barriers to investment and innovation in the Malaysian palm oil industry in Sabah. Journal of Rural Studies, 40, 46-58.

[21] Kata, R., \& Kusz, D. (2015). Barriers to the implementation of instruments assisting sustainable development of agriculture. Scientific Papers Series "Management, Economic Engineering in Agriculture and Rural Development", 15(1), 239-248.

[22] Marcelino-Aranda, M., Sánchez-García, M.C., \& Camacho, A.D. (2017). Theoretical-practical bases of a sustainable development model for rural communities with agricultural and livestock activities. Agricultura, Sociedad y Desarrollo, 14(1), 47-59.

\title{
Рівень еколого-економічної диверсифікації: методика оцінювання аспекту сталості сільськогосподарських підприємств \\ Світлана Іванівна Страпчук
}

\author{
Харківський національний аграрний університет ім. В.В. Докучаєва \\ 62483, учб. Містечко ХНАУ, п/в «Докучаєвське-2», Харківська область, Україна
}

\begin{abstract}
Анотація. Економіка екосистем та біорізноманіття як глобальна ініціатива у межах Програми ООН з охорони навколишнього середовища підкреслює важливість застосування системного підходу до оцінювання природних ресурсів та необхідність впровадження нових форм економічного зростання, що забезпечить сталий розвиток підприємств. Наявні практики господарювання сільськогосподарських підприємств, такі як монокультура, створюють постійне одноманітне навантаження на грунти та призводять до зменшення вмісту гумусу, сприяють ерозії, проте залишаються високоприбутковими. Зміна форм економічного зростання на користь впровадження сталих практик на зразок органічного виробництва, сталої інтенсифікації, ековиробництва потребує відповідних джерел фінансування, високого рівня екологічної свідомості та комплексних методик оцінювання екологоекономічних чинників. Метою дослідження є обгрунтування методичного підходу до комплексної оцінки екологоекономічної диверсифікації підприємства на основі принципів сталого розвитку, що дозволяє врахувати рівень різноманіття вирощуваних культур у взаємозв’язку зі структурою товарної продукції. Для досягнення мети були використані дані діяльності сільськогосподарських підприємств Харківської області, а також монографічний, графічний та статистичний методи дослідження. Аналіз та обробка даних здійснювалися за допомогою спеціалізованих програм Microsoft Excel та Statistica 10. У роботі представлено розроблений та апробований коефіцієнт еколого-економічної диверсифікації, що дозволяє оцінити рівень агробіорізноманіття посівних площ та товарної продукції сільськогосподарських підприємств за результатами господарювання за 2019 рік. В основу коефіцієнта покладена теорія інформації в контексті застосування індексу Шеннона-Уівера. Унаслідок пошуку залежності між коефіцієнтом еколого-економічної диверсифікації та прибутком у розрахунку на 1 га, твердження щодо поступової втрати прибутковості під час зростання кількості видів вирощуваних сільськогосподарських культур підтверджено. Проте існують підприємства, які під час розширення структури посівних площ утримують прибутковість. Практична значимість отриманих результатів полягає в оцінці можливості адаптації структури посівних площ до ринкових умов із урахуванням екологічних та економічних чинників
\end{abstract}

Ключові слова: сталий розвиток, біорізноманіття, монокультура, сільськогосподарське підприємство, коефіцієнт еколого-економічної диверсифікації, економічна ефективність 